\title{
STRATEGICALLY ORIENTED ORGANIZATION PERSONNEL DEVELOPMENT MANAGEMENT
}

Different approaches to the definition of "staff development" were analyzed in the article. The definition of "staff development" taking into account the strategic aspect was proposed in the article. External and internal factors of the organization were identified in the article. They determine the development of staff. Market, economic, political and legal, socio-cultural factors, the development of scientific and technological progress were attributed to external factors of the organization. General organizational factors, factors of organization and process, supporting factors are among the internal factors of the organization. The main goals of the organization's staff development were clarified in the article. The main goals of personnel development of the organization are: increasing the capacity of staff, increasing the competitiveness of the organization, ensuring the survival of the organization in the long run, reducing staff turnover in the organization, increasing productivity and efficiency. The close relationship between the organization's development strategy and its staff development strategy was proved in the article. The development strategy of the organization determines the main directions of staff development; they are designed for the long term. The strategy of personnel development of the organization in turn takes into accounts the strategic goals and guidelines of the organization. The relationship of the strategy of quality of products (services) with the strategy of personnel development of the organization was justified, the relationship of the strategy of innovative growth and development of the organization with the strategy of personnel development of the organization was justified, the relationship between the strategy of technical and technological development of the organization with the strategy of personnel development of the organization was substantiated in the study. Elements of the personnel development system of the organization were defined and the main directions of improving the system of personnel development in a competitive environment were outlined in the article.

Key words: staff development, personnel development system, professional development of staff, professional education, staff development strategy, organization development strategy, competitiveness.

DOI: https://doi.org/10.32838/2523-4803/70-3-31

УДК 339.13

\section{Самойлик Ю.В.}

доктор економічних наук, доцент,

професор кафедри економіки та міжнародних економічних відносин,

Полтавська державна аграрна академія

\section{Samoilyk Iuliia}

Poltava State Agrarian Academy

\section{СТРАТЕГІЯ ВПРОВАДЖЕННЯ ІННОВАЦІЙНИХ МЕТОДІВ УПРАВЛІННЯ АСОРТИМЕНТОМ ДИВЕРСИФІКОВАНИХ ПІДПРИЕМСТВ ПИВОВАРНОЇ ПРОМИСЛОВОСТІ}

\footnotetext{
У статті набули подальшого розвитку рекомендації щзодо управління асортиментом диверсифікованого підприємства. Проведено діагностику показників, щяо характеризують стан ринку пива. Виявлено лідерів ринку, тендениії та перспективи його розвитку. Визначено місце виробників крафтового пива на ринку пивної промисловості. Обтрунтовано роль інновацій у системі менеджменту диверсифікованого підприємства. Удосконалено метод АВС-XYZ-аналізу $і$ розповсюджено його застосування в систему інноваційного менеджменту диверсифікованого підприємства пивної промисловості. Розроблено рекомендації щзодо впровадження стратегій у розрізі напрямів діяльності та видів продукиії залежно від їхніх позицій у матрищі АBC-XYZ-аналізу. Обтрунтовано, щзо диверсифікаиія сприяє розподілу ризиків та отриманню додаткових прибутків за рахунок освоєння нових ринків.

Ключові слова: стратегія, диверсифікація, ринок пива, система менеджменту, інновації, управління асортиментом, АВС-ХYZ-аналіз, підприємство.
}

Постановка проблеми. Динамічний характер розвитку ринкових відносин зумовлює необхідність переосмислення класичних підходів до управління суб'єктами господарювання. Інновації стають базисом для стратегічного менеджменту та побудови дерева цілей для підприємства 3 активною ринковою пози- 
цією. Управлінські рішення інноваційного характеру мають забезпечувати конкурентоспроможність підприємства у довгостроковому періоді, при цьому вони грунтуються на значному залученні інтелектуального потенціалу, додаткових матеріальних ресурсів, інформаційних технологій, кваліфікованих кадрів, надійних партнерів та навиків стратегічного інноваційного управління.

На сьогоднішньому етапі розвитку економіки України інноваційна діяльність лише починає набувати популярності. Лише прогресивні підприємства розробляють стратегії впровадження інновацій у різні сфери діяльності. Особливо актуальним дане питання є для підприємств продуктової групи, які випускають не один вид продукції, тобто є диверсифікованими. До таких суб'єктів господарювання належать пивоварні підприємства, звичайно, виняток становлять крафтові невеликі пивоварні компанії, однак обсяг виробництва у цих компаніях становить нині лише близько 1\%. Дані підприємства потребують специфічних методів управління, оскільки їхня виробнича діяльність $є$ менш гнучкою через складнощі технологічного процесу. Тому своєчасне впровадження інновацій у різні сфери менеджменту сприятиме плавному переходу підприємств на новий рівень розвитку без необхідності прийняття антикризових рішень у короткий проміжок часу. Оскільки пивоварні підприємства насамперед формують свої конкурентні переваги за рахунок удосконалення продукту, то доцільно звернути увагу на впровадження інновацій у систему управління асортиментом. Таким чином, обгрунтування стратегічних рішень щодо впровадження інновацій у систему управління диверсифікованим підприємством набуває нових значень у сучасних економічних умовах, що й визначає актуальність проведення наукових досліджень у цьому напрямі.

Аналіз останніх досліджень і публікацій. Питання формування стратегії інноваційного розвитку привертають увагу низки науковців. Класиками теорії інновацій можна вважати Й. Шумпетера, Д. Кондратьєва, М. Портера, П. Друкера, К. Найта, Ф. Хаєка. Їх праці $\epsilon$ базовими для розроблення сучасних концепцій стратегічного інноваційного розвитку. Цікавими є дослідження таких науковців, як А.М. Безус, Д.С. Бутенко, О.І. Ковтун, Р.В. Короленко, В.В. Луцяк, А.В. Попеляр, М.Г. Чуйок та ін.

А.М. Безус і М.Г. Чуйок зазначають, що «підприємство, яке навіть не має абсолютних переваг, за рахунок інноваційного розвитку може отримати переваги, які оцінить споживач, що забезпечить виграш у конкурентній боротьбі у формі збільшення обсягу продажу як у натуральному, так і вартісному вимірах. Таким чином, інноваційна діяльність є одним 3 основних джерел отримання конкурентних переваг» [1]. Ми цілком погоджуємося з точкою зору науковців і вважаємо, що інноваційна діяльність є одним із домінуючих чинників формування конкурентоспроможності підприємства у довготерміновому періоді в умовах глобалізації економіки.
Ця теза підкреслюється в дослідженнях О.І. Ковтун, де також визначається важливість розроблення ефективної стратегії впровадження інновацій: «Стратегія визначає логіку бізнес-розвитку підприємства 3 метою забезпечення його довготривалої конкурентоспроможності та прибутковості в мінливому ринковому середовищі; вона повинна являти собою інноваційну бізнес-модель, яку вибиратиме підприємство до всіх своїх видів бізнес-діяльності для забезпечення їх конкурентоспроможності та прибутковості на основі інновацій у всіх ланках формування споживної вартості як окремо кожного продукту, так і сукупного бізнесу» [2, с. 45].

Особливості стратегії впровадження інновацій у діяльність та менеджмент виробничих підприємств розглядаються в працях В.В. Луцяк та А.В. Попеляр, які стверджують, що «виробничі підприємства прийшли до розуміння необхідності здійснення інноваційної діяльності; впровадження інновацій усе більше розглядається ними як єдиний спосіб підвищення конкурентоспроможності, підтримки високих темпів розвитку і рівня прибутковості» [3, с. 19]. Отже, більшість авторів уважає інновації невід'ємним складником діяльності підприємств. Разом із тим, незважаючи на значну кількість наукових праць, присвячених даним питанням, у сучасних економічних умовах стратегія впровадження інновацій потребує нових підходів, що викликає необхідність проведення додаткових досліджень у цьому напрямі.

Формулювання цілей статті. Метою роботи є діагностика показників розвитку ринку пива, обгрунтування інноваційних методів управління асортиментом диверсифікованого підприємства пивної промисловості, розроблення рекомендацій щодо впровадження стратегій у розрізі асортиментних позицій диверсифікованого підприємства.

Виклад основного матеріалу. Стратегія розвитку підприємства $є$ унікальною розробкою для кожного суб'єкта господарювання, тому формування певних узагальнених рекомендацій, які будуть дієвими для всіх без винятку, є практично неможливим. Однак формування основних стратегічних векторів упровадження інновацій для типових підприємств є доцільним. Дані рекомендації можуть стати основними базисними векторами стратегічного інноваційного розвитку для кожного суб'єкта господарювання, при цьому мають бути доповнені елементами стратегічного декомпонування.

Значні складнощі має формування стратегії диверсифікованого підприємства, тобто такого, на базі якого розвиваються пов'язані або непов'язані напрями діяльності [10]. Найбільш складним є процес управління конгломеративним підприємством, тобто об'єднанням уже диверсифікованих підприємств. Конгломерат - це одна з форм об'єднання, яка постійно перебуває під увагою Антимонопольного комітету. Такі підприємства не є типовими для ринкової економіки і в країнах із розвиненою її формою становлять близько $1 \%$. Якщо розглядати диверси- 
фіковані підприємства, то більш характерними для сучасного економічного світу $є$ середні підприємства, які працюють у споріднених галузях. Найбільше таких підприємств функціонує у продовольчій сфері, зокрема у пивоварній промисловості.

Експертна оцінка обсягу виробництва пива по Україні (крім пива безалкогольного з умістом спирту до 0,5 об. \%) свідчить, що за 12 місяців 2019 р. виробництво пива становило 180,2 млн дал, або 99,6\% до аналогічного періоду 2018 р., та виробництво солоду 339041 т, що становить 99,3\% до аналогічного періоду 2018 р. [5]. У 2019 р. індекс виробництва пива коливався близько нульової позначки, при цьому спостерігалося зростання рентабельності продажів. У першому кварталі 2019 р. спостерігається суттєве зростання обсягів виробництва пива. Але ці показники є набагато нижчими, ніж за аналогічний період 2018 р. (літній сезон 2018 р. характеризувався теплою погодою і чемпіонатом світу з футболу, що сприяло зростанню попиту на пиво). У 2019 р. порівняно з 2017 р. обсяги виробництва пива суттєво зросли (рис. 1).

За підсумками сезону значно поліпшила свої позиції «САН ІнБев Україна». ТМ «Оболонь» зберегла колишні обсяги і нині домінує на ринку пива [8]. Експертні дослідження свідчать, що лідерами серед виробників пива $€$ компанії «САН ІнБев Україна», «Карлсберг Україна», «Перша Приватна Броварня» і «Оболонь». У 2018 р. галузь пивоваріння сплатила до держбюджету України 4,7 млрд грн підакцизного податку. До ТОП-100 найбільших платників податків за 2018 р. увійшли п'ять ключових підприємств алкогольної галузі: «Карлсберг Україна» (2,93 млрд грн); «Національна горілчана компанія» (2,03 млрд грн); «САН ІнБев Україна» (1,6 млрд грн); «УДК» (1,53 млрд грн); «Оболонь» (1,25 млрд грн) [4]. Окрім класичного пива, що виготовляється на великих та середніх заводах, в Україні та світі збільшується виробництво крафтового напою. Також набуває поширення тренд на споживання «живого» пива, виробленого на регіональних заводах і крафтових пивоварнях.

В Україні частка крафтового пива в усьому ринку пива становить близько 1\%. Мода на вживання пива, звареного в маленьких броварнях, прийшла в країну зі США, де нині воно займає близько $25 \%$ ринку. За 2018 р. великі крафт-броварні і більш малі виробники загалом виготовили близько 17 млн л пива. На рівень розвитку пивного ринку вплинула хвиля кризи, що зменшила купівельну спроможність населення. Найбільшого спаду українські пивовари зазнали в 2015 р. (19,6\%). У наступних роках ситуація почала поступово покращуватися. У 2016 р. темп падіння ринку пивоваріння становив 7,4\%, а вже в наступному 2017 р. лише $1,3 \%$. При цьому рівень споживання крафтового пива продемонстрував зростання [9].

Щодо цінової ситуації на ринку пива, то спостерігається підвищення цін на даний напій. У 2018 р. літрова пляшка українського світлого пива подорожчала на 9\% (або на 1,2 грн) - до 15-19 грн, а з екзотичними або фруктовими добавками - до 29 грн, темного пива - 3 30 до 35 грн. Зростання ціни було зумовлено подорожчанням сировини - на $11 \%$ у середньому за рік і склотари - більше ніж на 40\%. Попри це, пиво лишається найдешевшим алкоголем, що відіграє роль у статистиці споживання різних видів алкогольних напоїв українцями. Унаслідок низької купівельної спроможності міцний алкоголь для українців - занадто дороге задоволення, тому набагато доступніше купувати літрову пляшку пива ціною близько 19 грн [4].

Типовим класичним підприємством пивоварної промисловості України, яка має стратегію спорідненої диверсифікації, можна вважати ПрАТ «Полтавпиво», історія якого починається з 1965 р. У радянський період пивзавод був частиною Полтавського об'єднання «Укрхарчопром». До середини 80-х років підприємство спеціалізувалося тільки на випуску пляшкового i розливного пива. У 1985 р. був побудований цех із

Обсяг, млн. дал

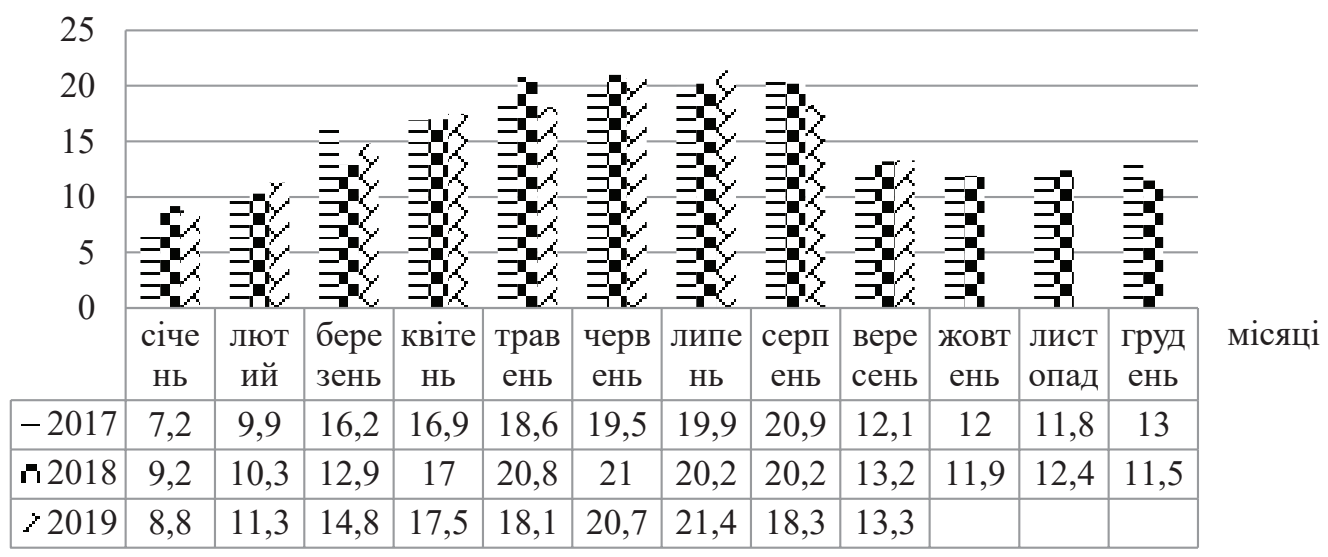

Рис. 1. Обсяги виробництва пива в Україні, 2017-2019 рр. (млн дал)

Джерело: узагальнено автором за [8] 
розливу безалкогольних газованих напоїв. В Україні $з$ 1998 р. почалася співпраця з німецькими технологами компанії Kaltenberg. У кінці 1990-х років була введена в дію автоматична лінія з розливу в КЕГ-тару потужністю 50 КЕГ на годину. Перші чотири циліндро-конічних комбі-танка в Україні були запущені в 1999 р. саме на полтавському заводі. У 2003 р. завершено та запущено варильний цех фірми Huppmann AG із повною комп'ютеризацією процесу варіння сусла. 32011 р. на ПрАТ «Фірма «Полтавпиво» продовжується повна реорганізація структур, модернізація виробництва, просування та впровадження нових методик і стратегій розвитку в цілому [6]. Нині основні стратегії товарної політики підприємства спрямовані на об'єднання всіх сортів пива і напоїв під одним брендом «Полтава».

Таким чином, управління асортиментом є одним із головних напрямів стратегічного менеджменту підприємства, що забезпечує достатній рівень конкурентоспроможності та популярність бренду компанії на локальному ринку. Управління асортиментом підприємства пивної промисловості включає: визначення оптимальної кількості видів та типів товарної продукції з урахуванням попиту на ринку, обгрунтування доповнення пивної продукції безалкогольною; формування необхідних обсягів виробництва продукції в розрізі видів та типів; визначення оптимальної кількості номенклатурних позицій, ширини та глибини асортименту; прогнозування показників асортиментної політики з урахуванням впливу ендогенних та екзогенних чинників; упровадження інновацій на різних етапах формування товарної політики; удосконалення рецептури та технологічного процесу; розроблення нових смаків; упровадження CRM-систем та інших автоматизованих програмних продуктів для оптимізації стратегій та методів взаємодії зі споживачами; обгрунтування асортименту продукції в межах усіх сегментів ринку, які об'єднує підприємство, та в розрізі каналів реалізації; забезпечення якості, безпечності та екологічності продукції.

Важливим напрямом системи управління асортиментом диверсифікованого продуктового підприємства, до яких належать суб'єкти господарювання пивної промисловості, є визначення оптимальних розмірів виробництва продукції, враховуючи іï популярність серед споживачів, коротких строків реалізації продукції, визначення оптимальних розмірів запасів готової продукції та сировини, необхідної для іiї виробництва. Для врахування зазначених напрямів системи управління асортиментом диверсифікованого підприємства доцільним є застосування елементів ABC-XYZаналізу. Цей метод прийнято використовувати в логістиці для оцінювання залишків певних видів продукції, при цьому враховується варіація попиту на них. Даний метод можна модифікувати, що дасть змогу проранжувати групи видів продукції підприємства, на основі чого проаналізувати залишки готової продукції на його складах, а замість показника варіації попиту оцінити питому вагу залишку в загальній сумі товарообігу підприємства. Як приклад застосування даної методики вибрано показники ПрАТ «Фірма «Полтавпиво». Найбільші обсяги продажу продукції підприємства припадають на літні місяці, оскільки саме у цей період підвищується попит на пиво та безалкогольні напої, тому в цей період особливо важливо обгрунтувати оптимальні обсяг виробництва продукції, щоб забезпечити повністю потреби споживачів та не створити значні залишки продукції (табл. 1).

Досліджуваним групам продукції підприємства були присвоєні такі значення: група А - об'єкти, сума часток із накопичувальним підсумком становить перші 50\% від загальної суми вартостей залишків пивної продукції та безалкогольних виробів підприємства; група В - об' єкти, сума часток із накопичувальним підсумком яких становить від 50\% до 80\% від загальної вартості залишків; група С - об'єкти, сума часток із накопичувальним підсумком яких становить від 80\% до 100\% від загальної вартості залишків. За результатами розрахунку виявлено, що найбільшу питому вагу в структурі залишків продукції ПрАТ «Фірма «Полтавпиво» (45,3\% - 278,7 тис дал) посідають види продукції під номерами 13 (Лимонадний Джо), 1 (Диканські вечори), 6 (Rigas), 7 (Полтавське класік), 18 (ЛимонадоВо «Лимонад»), 2 (Жигулівське), питома вага яких у загальній кількості магазинів 26,1\% - група А (табл. 2).

До групи В (продукція із середнім рівнем залишків продукції - 198,6 дал, або 32,2\% від загальних залишків) належить шість груп продукції (26,1\%). Решта груп продукції (11 груп, або 47,8\%) знаходиться в групі $\mathrm{C}$, яка характеризується незначною часткою залишків за групами продукції.

ABC-XYZ-аналіз оснований на концепції критерію Парето. Концепція ефективності конкурентної ринкової системи базується на понятті «ефективність за Парето». Ефективність за Парето (Парето-оптимум) означає, що ресурси розподілені оптимально, якщо ніхто не може поліпшити свого становища, не погіршуючи становища іншого.

Основним критерієм ефективності за Парето є наявність або відсутність розтрати ресурсів. Паретооптимальними є розподіли, за яких будь-які подальші вигідні зміни неможливі.

Окрім визначення питомої ваги запасів по кожній групі продукції ПрАТ «Фірма «Полтавпиво», у загальних залишках продукції на наступний місяць доцільно проаналізувати частки залишків від середньомісячного товарообігу підприємства. Для цього проведений XYZаналіз. У результаті аналізу виявлено, що найбільшу питому вагу у товарній продукції $(36,1 \%)$ займають залишки продукції під номерами 15, 22, 20, 7, 16, 10, питома вага яких у загальній кількості видів продукції становить $26,1 \%$. Середню частку залишків у товарній продукції $(23,1 \%)$ мають сім видів продукції (30,4\%). Решта видів продукції $(43,5 \%)$ належать до групи Z 3 незначною часткою залишків - 9,9\% (табл. 3).

Об'єднані результати розрахунків можна представити у вигляді матриці ABC-XYZ, яка дає змогу визначити позиції груп продукції за показниками 
Таблиця 1

Показники обсягів реалізації та залишків продукції ПрАТ «Фірма «Полтавпиво», 2019 р.

\begin{tabular}{|c|c|c|c|c|c|c|c|}
\hline \multirow{3}{*}{ Види продукції } & \multicolumn{4}{|c|}{ Обсяг реалізації, тис дал } & \multicolumn{2}{|c|}{$\begin{array}{c}\text { Середньо-місячні } \\
\text { залишки продукції }\end{array}$} & \multirow{3}{*}{$\begin{array}{c}\text { Питома вага } \\
\text { залишку } \\
\text { в товарній } \\
\text { продукції, \% }\end{array}$} \\
\hline & \multirow{2}{*}{ червень } & \multirow{2}{*}{ липень } & \multirow{2}{*}{ серпень } & \multirow{2}{*}{$\begin{array}{l}\text { у середньому } \\
\text { за } 3 \text { місяці }\end{array}$} & обсяг, & структура, & \\
\hline & & & & & тис дал & $\%$ & \\
\hline 1. Диканські вечори & 394,0 & 409,1 & 435,5 & 412,9 & 51,4 & 8,3 & 12,4 \\
\hline 2. Жигулівське & 234,1 & 243,1 & 258,8 & 245,3 & 41,4 & 6,7 & 16,9 \\
\hline 3. Бочкове & 613,3 & 636,8 & 677,9 & 642,7 & 18,4 & 3,0 & 2,9 \\
\hline 4. Ячмінний колос & 303,5 & 315,2 & 335,5 & 318,1 & 39,7 & 6,4 & 12,5 \\
\hline 5. Ай-Нікола & 210,3 & 218,4 & 232,5 & 220,4 & 47,4 & 7,7 & 21,5 \\
\hline 6. Rigas & 462,8 & 480,5 & 511,5 & 484,9 & 41,6 & 6,8 & 8,6 \\
\hline 7. Полтавське класік & 22,1 & 23,0 & 24,5 & 23,2 & 8,4 & 1,4 & 36,2 \\
\hline 8. Нефільтроване солодове & 159,6 & 165,7 & 176,4 & 167,3 & 21,4 & 3,5 & 12,8 \\
\hline 9. Діжка розливного & 75,0 & 77,9 & 82,9 & 78,6 & 18,3 & 3,0 & 23,3 \\
\hline 10. Діжка свіжого & 89,0 & 92,4 & 98,3 & 93,2 & 27,4 & 4,4 & 29,4 \\
\hline $\begin{array}{l}\text { 11. Квас хлібний } \\
\text { «Полтавський хлібний» }\end{array}$ & 378,3 & 392,7 & 418,1 & 396,3 & 24,6 & 4,0 & 6,2 \\
\hline 12. Тьотя Груша & 161,4 & 167,6 & 178,4 & 169,1 & 37,8 & 6,1 & 22,4 \\
\hline 13. Лимонадний Джо & 243,1 & 252,4 & 268,7 & 254,7 & 55,4 & 9,0 & 21,8 \\
\hline 14. Мохіто & 65,5 & 68,1 & 72,4 & 68,7 & 15,4 & 2,5 & 22,4 \\
\hline 15. Тархун & 34,3 & 35,7 & 38,0 & 36,0 & 19,7 & 3,2 & 54,8 \\
\hline 16. Полтава Буратіно & 53,7 & 55,8 & 59,4 & 56,3 & 19,1 & 3,1 & 33,9 \\
\hline 17. Екстра-Сітро & 29,4 & 30,5 & 32,5 & 30,8 & 8,4 & 1,4 & 27,3 \\
\hline 18. ЛимонадоВо «Лимонад» & 402,5 & 417,9 & 444,8 & 421,7 & 41,5 & 6,7 & 9,8 \\
\hline 19. ЛимонадоВо «Тархун» & 114,2 & 118,6 & 126,2 & 119,7 & 31,2 & 5,1 & 26,1 \\
\hline 20. ЛимонадоВо «Вишня» & 99,0 & 102,8 & 109,4 & 103,7 & 37,9 & 6,2 & 36,5 \\
\hline 21.ЛимонадоВо «Апельсин» & 1,8 & 1,8 & 2,0 & 1,9 & 0,5 & 0,1 & 26,8 \\
\hline 22. Озонована вода & 17,6 & 18,3 & 19,5 & 18,5 & 7,1 & 1,2 & 38,4 \\
\hline 23. Інші види продукції & 25,2 & 26,2 & 27,9 & 26,4 & 1,8 & 0,3 & 6,8 \\
\hline Всього & 3170,9 & 3210,3 & 3258,5 & 3213,2 & 615,8 & 100,0 & 19,2 \\
\hline
\end{tabular}

Джерело: узагальнено автором за даними підприсмства

Таблиця 2

Результати АВС-аналізу залишків продукції ПрАТ «Фірма «Полтавпиво», 2019 р.

\begin{tabular}{|c|c|c|c|c|}
\hline \multirow{2}{*}{ Група } & \multicolumn{2}{|c|}{ Середньомісячі залишки } & \multicolumn{2}{c|}{ Кількість груп продукції } \\
\cline { 2 - 5 } & дал & структура, \% & кількість, од. & структура, \% \\
\hline А & 278,7 & 45,3 & 6 & 26,1 \\
\hline В & 198,6 & 32,2 & 6 & 26,1 \\
\hline С & 138,5 & 22,5 & 11 & 47,8 \\
\hline Всього & 615,8 & 100,0 & 23 & 100,0 \\
\hline
\end{tabular}

Джерело: розраховано автором

Таблиця 3

Результати XYZ-аналізу залишків продукції ПрАТ «Фірма «Полтавпиво», 2019 р.

\begin{tabular}{|c|c|c|c|c|c|}
\hline \multirow{2}{*}{ Група } & \multicolumn{2}{|c|}{ Середньомісячні залишки } & \multirow{2}{*}{$\begin{array}{c}\text { Питома вага залишків } \\
\text { продукції у товарній } \\
\text { продукції, \% }\end{array}$} & \multicolumn{2}{|c|}{ Групи продукції } \\
\hline & обсяг, дал & структура, \% & & кількість, од. & структура, \% \\
\hline X & 119,6 & 19,4 & 36,1 & 6 & 26,1 \\
\hline $\mathrm{Y}$ & 167,0 & 27,1 & 23,1 & 7 & 30,4 \\
\hline $\mathrm{Z}$ & 329,2 & 53,5 & 9,9 & 10 & 43,5 \\
\hline Всього & 615,8 & 100,0 & $\mathrm{x}$ & 23 & 100,0 \\
\hline
\end{tabular}

Джерело: розраховано автором

ефективності управління асортиментом продукції на основі аналізу питомої ваги залишків видів продукції в загальній сумі залишків та відносно товарообігу в розрізі номенклатурних позицій (табл. 4).
Відповідно до даних матриці ABC-XYZ, можна визначити основні напрями стратегічного управління асортиментом по кожній групі продукції ПрАТ «Фірма «Полтавпиво». Найбільш привабливу 
Матриця АВC-XYZ-аналізу залишків продукції ПрАТ «Фірма «Полтавпиво», 2019 р.

\begin{tabular}{|c|c|c|c|}
\hline & ГРУПА X & ГРУПА Y & ГРУПА Z \\
\hline ГРУПА А & - & 13 & $1,5,6,18,2$ \\
\hline ГРУПА В & 20,10 & 12,19 & 4,11 \\
\hline ГРУПА С & $15,16,7,22,21$ & $9,14,17$ & $8,3,23$ \\
\hline
\end{tabular}

Джерело: розраховано автором

позицію (квадрат CZ) у ПрАТ «Фірма «Полтавпиво» займають групи продукції: № 8 (нефільтроване солодове пиво), № 3 (бочкове) та № 23 (інші види продукції).

Частка залишків по цих групах продукції є найменшою як у товарній продукції, так і в загальній вартості залишків продукції підприємства. Першочергової уваги заслуговують групи продукції № 20 (ЛимонадВо «Вишня») та № 10 (Діжка свіжого), положення яких $є$ найменш вигідним (квадрат ВХ). За рівнем товарообігу ці групи продукції займають відповідно 13-е та 14-е місця.

Отже, для пива «Бочкове» та «Нефільтроване солодове» доцільним $є$ поєднання двох основних стратегій:

1) посилення позиції на ринку, за якої підприємство має спрямувати всі наявні ресурси на існуючий ринок для завоювання найкращих позицій та сильних конкурентних переваг. Для реалізації цієї стратегії потрібна ефективна маркетингова кампанія. Дана стратегія може бути поєднана зі стратегією горизонтальної інтеграції, яка полягає у встановленні контролю над конкурентами;

2) стратегія розвитку ринку - полягає у пошуку нових ринків для вже виробленого продукту. Продукція ПрАТ «Фірма «Полтавпиво» переважно продається на локальному ринку. Ураховуючи потенціал підприємства, доцільним є вихід на ринок інших регіонів насамперед із продукцією, яка займає найкращу позицію - пиво «Бочкове» та «Нефільтроване».

Оскільки першочергової уваги заслуговують групи продукції № 20 (ЛимонадВо «Вишня») та № 10 (Діжка свіжого), то для даних видів продукції доцільною є конкурентна стратегія розвитку продукту, яка передбачає концентрування зусиль на розвитку існуючого продукту (підвищення його якості, диференціація або модифікація продукту).

Для інших асортиментних позицій ПрАТ «Фірма «Полтавпиво» доцільною $є$ стратегія обмеженого зростання, яка передбачає прогнозування на наступний період незначного перевищення досягнутих поточних результатів, при цьому заплановані показники можуть бути скориговані залежно від змін на конкурентному ринку. Якщо даний вид продукції забезпечує підприємству стабільні прибутки й $€$ достатньо конкурентоспроможним, то доцільно дотримуватися раніше розробленої та впровадженої стратегії, орієнтація на існуючу стратегію у цьому разі $є$ найменш ризикованим напрямом розвитку, інвестиції, отримані від продажу цієї продукції, можуть бути використані для розвитку інших продуктів та ринків, тобто може бути застосований елемент стратегії «дійних корів».

У цілому варто зазначити, що для типових підприємств пивної промисловості доцільне постійне оновлення асортименту шляхом його доповнення спорідненими групами товарів (різні сорти пива та безалкогольної продукції), а також упровадження абсолютно нової продукції, яка не пов'язана з основним напрямом підприємницької діяльності, наприклад мінеральної води або фруктового пива, що забезпечить розподіл ризиків та проникнення на нові ринки.

Висновки. Ринок пива в Україні перебуває на етапі зростання. У період кризи 2015 р. відбулося суттєве падіння обсягів виробництва та продажу пива, а також доходів галузі, однак наприкінці 2019 р. пивна промисловість продемонструвала майже повне відновлення після кризи. Разом із тим початок 2020 р. характеризується всесвітньою пандемією та економічною кризою, тому перше півріччя 2020 р. для пивної промисловості, як і для більшості галузей економіки, виявилося доволі несприятливим.

Основними перспективними напрямами розвитку пивного сегменту ринку після кризового періоду $€$ оптимізація асортименту пивної продукції, розроблення нової стратегії збуту з диверсифікацією каналів реалізації, удосконалення рецептури приготування напою, виведення на ринок нових видів продукції, формування конкурентних переваг порівняно зі світовими виробниками.

Основою стратегії розвитку підприємств пивної промисловості має стати інноваційний підхід до управління в усіх функціональних сферах. У системі управління асортиментом диверсифікованого підприємства, крім випуску нових продуктів, інноваційні стратегії мають проявлятися й у методах управління асортиментом. Доцільним є врахування критерію ефективності Парето, який покладений в основу ABC-XYZ-аналізу. Модифікація критеріїв даного методу дає змогу визначити сильні та слабкі асортиментні позиції у продуктовому портфелі підприємства та сформулювати відповідні стратегії для кожної групи. Так, для сильних продуктових груп доцільними є стратегії захоплення і розвитку ринку з елементами горизонтальної інтеграції. Для слабких позицій необхідною є стратегія розвитку та диференціації продукту. Для продукції зі стабільними показниками обгрунтованою є стратегія обмеженого зростання з елементами стратегії «дійних корів». 
Отже, інноваційні методи управління асортиментом дають змогу оптимізувати витрати на виробництво та реалізацію продукції, спростити процес прийняття управлінських рішень щодо диверсифікації діяльності підприємства.
Перспективи дослідження в даному напрямі полягають в обгрунтуванні перспективних напрямів збуту продукції пивної промисловості з урахуванням специфіки даного продукту та особливостей його просування.

\section{Список літератури:}

1. Безус А.М., Чуйок М.Г. Стратегія підвищення інноваційної діяльності підприємства. Ефективна економіка. 2018. № 1. URL : http://www.economy.nayka.com.ua/pdf/1_2018/45.pdf (дата звернення: 05.05.2020).

2. Ковтун О.І. Інноваційні стратегії підприємств: теоретико-методологічні засади. Економіка України. 2013. № 4(617). С. 44-56.

3. Луцяк В.В., Попеляр А.В. Інноваційна стратегія виробничого підприємства. Вісник Хмельницького національного університету. 2011. № 6. Т. 2. С. 18-21.

4. Названо лідера алкогольної індустрії України. URL : https://landlord.ua/news/nazvano-lidera-alkoholnoi-industriiukrainy (дата звернення: 27.04.2020).

5. Обсяг виробництва за 12 місяців 2019. URL : http://ukrpivo.com/obsyag-virobnitstva-za-12-misyatsiv-2019-roku. (дата звернення: 27.04.2020).

6. Офіційний сайт ПрАТ «Фірма «Полтавпиво». URL : http://poltavpivo.com/ua (дата звернення: 05.05.2020).

7. Парето В. Трансформация демократии / пер. с итал. М. Юсима. Москва : Территория будущего, 2011. 208 с.

8. Пивное дело 3-2019. Рынок пива Украины 2019: компании и бренды. URL : https://www.pivnoe-delo.info/ 2019/11/09/pivnoe-delo-3-2019-rynok-piva-ukrainy-2019-kompanii-i-brendy (дата звернення: 05.05.2020).

9. Ринок крафтового пива України (2019 рік). URL : http://monetary-flow.com/rinok-kraftovogo-piva-v-ukran-2019-rk. (дата звернення: 05.05.2020).

10. Самойлик Ю.В. Аспекти економічної диверсифікації в системі ринкових відносин. Наукові праці Полтавської державної аграрної академії. 2014. Вип. 2(5) Т. 3. С. 276-280.

\section{References:}

1. Bezus A.M., Chuiok M.H. (2018) Stratehiia pidvyshchennia innovatsiinoi diialnosti pidpryiemstva [Strategy to increase the innovative activity of the enterprise] Efektyvna ekonomika. no 1. Available at: http://www.economy.nayka.com.ua/ pdf/1_2018/45.pdf (accessed 5.05.2020).

2. Kovtun O.I. (2013) Innovacijni strateghiji pidpryjemstv: teoretyko-metodologhichni zasady [Innovative strategies of enterprises: theoretical and methodological principles]. Ekonomika Ukrajiny, no.4 (617), pp. 44-56.

3. Lucjak V.V., Popeljar A.V. (2011) Innovacijna strateghija vyrobnychogho pidpryjemstva [Innovative strategy of a production enterprise]. Visnyk Khmeljnycjkogho nacionaljnogho universytetu, no 6, vol. 2, pp. 18-21.

4. Named the leader of the alcohol industry of Ukraine. Available at: https://landlord.ua/news/nazvano-lidera-alkoholnoiindustrii-ukrainy (accessed 5.05.2020).

5. Production volume for 12 months of 2019. Available at: http://ukrpivo.com/obsyag-virobnitstva-za-12-misyatsiv-2019roku. (accessed 5.05.2020).

6. Official site of PJSC «Firma «Poltavpyvo». Available at: http://poltavpivo.com/ua (accessed 5.05.2020).

7. Pareto V. (2011) Transformacyja demokratyy [Transformation of democracy] translation from Italian. M. Yusima. Moskow. Terrytoryja budushhegho. $208 \mathrm{p}$.

8. Beer business 3-2019. Beer market of Ukraine 2019: companies and brands. Available at: https://www.pivnoe-delo.info/ 2019/11/09/pivnoe-delo-3-2019-rynok-piva-ukrainy-2019-kompanii-i-brendy (accessed 5.05.2020).

9. Craft beer market of Ukraine (2019) Available at: http://monetary-flow.com/rinok-kraftovogo-piva-v-ukran-2019-rk. (accessed 5.05.2020).

10. Samojlyk Iu.V. (2014) Aspekty ekonomichnoji dyversyfikaciji v systemi rynkovykh vidnosyn [Aspects of economic diversification in the system of market relations]. Naukovi praci Poltavsjkoji derzhavnoji aghrarnoji akademiji, issue. 2 (5), vol. 3, pp. 276-280. 


\section{СТРАТЕГИЯ ВНЕДРЕНИЯ ИННОВАЦИОННЫХ МЕТОДОВ УПРАВЛЕНИЯ АССОРТИМЕНТОМ ДИВЕРСИФИЦИРОВАННОГО ПРЕДПРИЯТИЯ ПИВОВАРЕННОЙ ПРОМЫШЛЕННОСТИ}

В статье получили дальнейшее развитие рекомендации по управлению ассортиментом диверсифицированного предприятия. Проведена диагностика показателей, характеризующих состояние рынка пива. Выявлены лидеры рынка, тенденциии и перспективы его развития. Определено место производителей крафтового пива на рынке пивной промыпленности. Обоснована роль инноваций в системе менеджмента диверсифииированного предприятия. Усовершенствован метод АBC-XYZ-анализа и распространено его применение в системе инноваичинного менеджмента диверсифицированного предприятия пивной промышленности. Разработаны рекомендаиии по внедрению стратегий в разрезе направлений деятельности и видов продукиии в зависимости от их позиций в матрице $A B C$-XYZ-анализа. Обосновано, что диверсификация способствует распределению рисков и получению дополнительных доходов за счет освоения новых рынков.

Ключевые слова: стратегия, диверсификация, рынок пива, система менеджмента, инновации, управление ассортиментом, АВС-ХYZ-анализ, предприятие.

\section{STRATEGY FOR IMPLEMENTATION OF THE ASSORTMENT MANAGEMENT INNOVATIVE METHODS OF THE DIVERSIFIED ENTERPRISES OF THE BREWERY INDUSTRY}

In the article, the recommendations for the assortment's management of a diversified enterprise have been further developed. Diagnosis of indicators characterizing the beer market development has been carried out. Market leaders, tendencies and prospects of its development are revealed. The place of craft beer producers in the beer industry market has been determined. The role of innovations in the diversified enterprise management system has been substantiated. It has been proved that determine the optimal size of production is an important direction of the assortment management system of the diversified food enterprises, which include business entities of the beer industry. This process should take into account products popularity among consumers, short lead times, the optimal size of the finished products and raw materials needed for its production stocks. The method of ABC-XYZ-analysis has been improved and its application in the innovative management system of the beer industry diversified enterprise has been extended. This method has been modified, which allowed to ranks products groups of the enterprise, to analyze the finished products balances in its warehouses and to estimate the balance share in the total enterprise's turnover. or an example of this method application, the indicators of PJSC "Firm "PoltavPivo" have chosen. Modification of the ABC-XYZ-analysis criteria allows to determine the strong and weak assortment positions in the product portfolio of the enterprise and to formulate appropriate strategies for each group. Thus, for strong product groups, strategies for capturing and developing the market with elements of horizontal integration are appropriate. For weak positions, a strategy of product development and differentiation is needed. For products with stable indicators, a strategy of limited growth with elements of the "milking cows"strategy is justified. It has been substantiated that diversification contributes to the risk's distribution and becomes additional profits through the new markets development. Innovative methods of assortment management make it possible to optimize the costs of production and product's sales, to simplify the process of making management decisions to diversify the enterprises activities.

Key words: strategy, diversification, beer market, management system, innovation, assortment management, $A B C-X Y Z$ analysis, enterprise. 